DOI :10.31357/fapsmst.2010.00403

Comparison of Berberine content in Berberis ceylanica Schneider and market samples of Daruharidra

\author{
Thamara Kumari Nawarathna
}

Thesis submitted to the University of Sri Jayawardenepura in partial fulfillment of the requirements for the award of the Master of Science in Industrial Utilization of Medicinal and Aromatic plants on 2010 . 


\section{DECLARATION}

The work described in this thesis was carried out by me under the supervision of Dr. G.A.S.Premakumara (Head, Herbal Technology Section, Industrial Technology Institute, Colombo) and Prof. S.Samarasinghe (Head, Department of Chemistry, University of Sri Jayawardenapura) and a report on this has not been submitted in whole or in part to any university or any other institution for another Degree.

$24: 06: 2010 \ldots \ldots$

Date
Fitmatmpatm

Signature of the candidate 
We certify that the above statement made by the candidate is true and that this thesis is suitable for submission to the university for the purpose of evaluation.

1. Dr. G.A.S.Premakumara

Date $24.06: 2010$

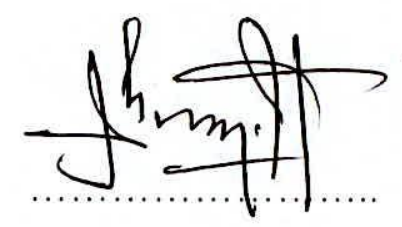

Signature

2. Prof. S.Samarasinghe

Date $07 / 07 / 2010$

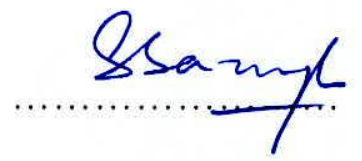

Signature 


\section{Table of Contents}

Page No

List of Tables $\quad$ iv

List of Figures vi

List of Plates $\quad$ ix

Acknowledgement $\quad \mathrm{x}$

Abstract $\quad$ xii

\section{CHAPTER 1 - INTRODUCTION}

1.1. General Introduction 1

1.2. Objectives of the study 2

1.3. Description and distribution of genus Berberis 3

1.4. Taxonomy and distribution of Berberis aristata 6

1.4.1. Powder microscopy of Berberis aristata 7

1.5. Taxonomy and distribution of Berberis ceylanica 10

1.5.1. Powder microscopy of Berberis ceylanica 11

1.6. Chemical composition of Berberis aristata 15

1.7. Medicinal uses of Berberis aristata 17

1.8. Scientific investigations of bioactivities of Berberis aristata 19

CHAPTER 2 - MATERIALS AND METHODS

2.1. Collection of plant materials 20

2.1.1. Collection of Berberis ceylanica 20

2.1.2. Collection of market samples of Daruharidra 20

2.2. Preparation of samples of Berberis ceylanica and Daruharidra 20

2.3. Determination of physico-chemical parameters 21 
2.3.1. Determination of moisture content

2.3.2. Determination of total ash content 21

2.3.3. Determination of acid insoluble ash content 22

2.3.4. Determination of water soluble ash content 22

2.3.5. Determination of ethanol extractable matter 23

2.3.6. Determination of water soluble extractable matter 23

\subsection{Different extraction procedures and development of TLC}

fingerprints for $B$. ceylanica and Daruharidra

2.4.1. Preparation of Berberis ceylanica and market samples of Daruharidra methanolic extracts

2.4.1.1. Development of TLC fingerprints of Berberis ceylanica and market samples of Daruharidra methanolic extracts

2.4.2. Sequential fractionation of Berberis ceylanica and Daruharidra samples

2.4.2.1. Development of TLC fingerprints of Berberis ceylanica and Daruharidra fractions

2.4.3. Preparation of Berberis ceylanica and Daruharidra methanol/dichloromethane $(1: 1)$ extracts

2.4.3.1. Development of TLC fingerprints of Berberis ceylanica and

Daruharidra methanol/dichloromethane $(1: 1)$ extracts

2.4.3.2. Comparison of the TLC fingerprint profiles of Berberis ceylanica and Daruharidra methanol/dichloromethane $(1: 1)$ extracts by increasing the polarity of the solvent system

2.5. Quantification of berberine content in Berberis ceylanica and Daruharidra samples 


\section{CHAPTER 3 - RESULTS}

3.1. Physico-chemical parameters of Berberis ceylanica and Daruharidra samples

3.2. Preparation of methanolic extracts and developments of TLC fingerprints of Berberis ceylanica and Daruharidra samples

3.3. Development of TLC fingerprints of Berberis ceylanica and Daruharidra fractions

3.3.1. TLC fingerprints developed for hexane fraction (HF) 39

3.3.2. TLC fingerprints developed for dichloromethane fraction (DF) 41

3.3.3. TLC fingerprints developed for ethyl acetate fraction (EAF) 42

3.3.4. TLC fingerprints developed for methanol fraction (MF) 44

3.4. Preparation of methanol/dichloromethane (1:1) extracts and development of TLC fingerprints of Berberis ceylanica and Daruharidra samples

3.4.1. TLC profiles of methanol/dichloromethane extracts by increasing $\begin{array}{ll}\text { the polarity of the solvent system } & 51\end{array}$

3.5. Berberine content of Berberis ceylanica and Daruharidra samples 55 


\section{Lists of Tables}

Page No

Table 1.1. Morphological differences among Berberis ceylanica, Berberis tinctoria and Berberis wightiana

Table 1.2. Alkaloids found in some selected species of Berberis

Table 1.3. Medicinal uses of Berberis aristata

Table 1.4. Some selected investigations of bioactivities of Berberis aristata

Table 3.1. Physico-chemical parameters of stem parts of Berberis ceylanica and Daruharidra

Table 3.2. Yields of Berberis ceylanica and Daruharidra methanolic extract

Table 3.3. $\mathrm{R}_{\mathrm{f}}$ values and colours of the spots present in the TLC fingerprints of Berberis ceylanica and Daruharidra methanolic extracts after spraying the Dragendorff's reagent

Table 3.4. $R_{f}$ values and colours of the spots present in the TLC fingerprints of Berberis ceylanica and Daruharidra methanolic extracts after spraying the Anisaldehyde sulfuric reagent

Table 3.5. Yields of Berberis ceylanica and Daruharidra methanol/dichloromethane $(1: 1)$ extracts

Table 3.6. $\mathrm{R}_{\mathrm{f}}$ values and colours of the spots present in the TLC fingerprints of Berberis ceylanica and Daruharidra methanol/dichloromethane (1:1) extracts after spraying the Dragendorff's reagent 
Table 3.7. $\mathrm{R}_{\mathrm{f}}$ values and colours of the spots present in the TLC fingerprints of Berberis ceylanica and Daruharidra methanol/dichloromethane (1:1) extracts after spraying the Anisaldehyde sulfuric reagent

Table 3.8. Berberine content of methanolic and methanol/dichloromethane extracts of Berberis ceylanica and Daruharidra 


\section{Lists of Figures}

\section{Page No}

Fig. 1.1. Powder microscopy of stem of Berberis aristata

Fig. 1.2. Powder microscopy of stem of Berberis ceylanica

Fig. 1.3. Some selected structures of alkaloids present in Berberis aristata

Fig. 2.1. Diagrammatic representative of the spots of hexane, dichloromethane Ethyl acetate and methanol fractions of Berberis ceylanica and Daruharidra

Fig. 3.1. The TLC fingerprints of Berberis ceylanica and Daruharidra methanolic extracts under UV light

Fig. 3.2. The TLC profiles of methanolic extracts of Berberis ceylanica and Daruharidra after spraying the Dragendorff's reagent

Fig. 3.3. The TLC profiles of methanolic extracts of Berberis ceylanica and Daruharidra after spraying the Anisaldehyde sulfuric reagent

Fig. 3.4. The TLC profiles of Berberis ceylanica and Daruharidra n-hexane fractions under UV light

Fig. 3.5. The TLC profiles of Berberis ceylanica and Daruharidra n-hexane fractions after spraying the Anisaldehyde sulfuric reagent 
Fig. 3.6. The TLC profiles of Berberis ceylanica and Daruharidra dichloromethane fractions under UV light

Fig. 3.7. The TLC profiles of Berberis ceylanica and Daruharidra dichloromethane fractions after spraying the Anisaldehyde sulfuric reagent

Fig. 3.8. The TLC profiles of Berberis ceylanica and Daruharidra ethyl acetate fractions under UV light

Fig. 3.9. The TLC profiles of Berberis ceylanica and Daruharidra ethyl acetate fractions after spraying the Anisaldehyde sulfuric reagent

Fig. 3.10. The TLC profiles of Berberis ceylanica and Daruharidra methanol fractions under UV light

Fig. 3.11. The TLC profiles of Berberis ceylanica and Daruharidra methanol fractions after spraying the Anisaldehyde sulfuric reagent

Fig. 3.12. The TLC fingerprints of methanol/dichloromethane extracts of Berberis ceylanica and Daruharidra under UV light

Fig. 3.13. The TLC fingerprints of methanol/dichloromethane extracts of Berberis ceylanica and Daruharidra after spraying the Dragendorff's reagent

Fig. 3.14. The TLC fingerprints of methanol/dichloromethane extracts of Berberis ceylanica and Daruharidra after spraying the Anisaldehyde sulfuric reagent

Fig. 3.15. The TLC fingerprints of methanol/dichloromethane extracts of Berberis ceylanica and Daruharidra under UV light

(eluent $\mathrm{MeOH}: \mathrm{CH}_{2} \mathrm{Cl}_{2}: \mathrm{C}_{6} \mathrm{H}_{12} \quad 0.3: 3.7: 1$ ) 
Fig. 3.16. The TLC fingerprints of methanol/dichloromethane extracts of Berberis ceylanica and Daruharidra under UV light (eluent $\mathrm{MeOH}: \mathrm{CH}_{2} \mathrm{Cl}_{2}: \mathrm{C}_{6} \mathrm{H}_{12} \quad$ 0.7:3.3:1 )

Fig. 3.17. The TLC fingerprints of methanol/dichloromethane extracts of Berberis ceylanica and Daruharidra under UV light

(eluent butanol:EtoAc:Acetic acid:water 1.5:2:1:0.5)

Fig. 3.18. The TLC fingerprints of methanol/dichloromethane extracts of Berberis ceylanica and Daruharidra under UV light (eluent butanol:EtoAc:Acetic acid:water 1.2:2:1.3:0.5)

Fig. 3.19. The TLC fingerprints of methanol/dichloromethane extracts of Berberis ceylanica and Daruharidra under UV light (eluent butanol:EtoAc:Acetic acid:water 1.2:1.94:1.3:0.56)

Fig. 3.20. The TLC fingerprints of methanol/dichloromethane extracts of Berberis ceylanica and Daruharidra under UV light (eluent butanol:EtoAc:Acetic acid:water 1.2:1.81:1.3:0.69)

Fig. 3.21. The TLC fingerprints of methanol/dichloromethane extracts of Berberis ceylanica and Daruharidra under UV light (eluent butanol:EtoAc:Acetic acid:water 1.2:1.56:1.3:0.94) 


\section{Lists of Plates}

Page No

Plate 1.1. (A) Flowering stage and (B) whole plant of Berberis aristata 8

Plate 1.2. (A) Flowering stage and (B) whole plant of Berberis ceylanica 12

Plate 1.3. Presence of lichens on the stem of Berberis ceylanica 13 


\section{ACKNOWLEDGEMENT}

My sincere thanks and heartfelt gratitude to my supervisors Dr. G.A.S. Premakumara (Head, Herbal Technology Section, Industrial Technology Institute) and Prof. S. Samarasinghe (Head, Department of Chemistry, University of Sri Jayawardenapura) for their invaluable guidance and advice throughout this study.

It has been a great privilege to have worked with Dr. G.A.S. Premakumara as he has been a constant source of inspiration and encouragement. A deep sense of gratitude is expressed to him for his generous advice and guidance in conducting this investigation.

I extend my special thanks to Prof. S. Samarasinghe for her unhesitant help and cooperation at all times has contributed immensely to make this thesis a success.

I am grateful to Mr. P. Marasinghe(Senior Scientist, Bandaranayake Memorial Ayurvedic Research Institute) for his valuable advice, encouragement and suggestions through out the research project.

Thanks also extended to Prof. A. Abeysekara (Dean, Faculty of Applied Science, University of Sri Jayawardenapura) for his advice, guidance and cooperation for this study.

I wish to express my thanks to Mrs. R. Gunawardene (Commissioner, Department of Ayurveda) and Dr. D. Senasekara (Director, Bandaranayake Memorial Ayurvedic Research Institute) for granting me the study leave to undertake this project. 
I would like to thank the Director, Industrial Technology Institute for providing necessary resources and facilities during this study.

I extend my special thanks with deep sense of gratitude more than as can be expressed here, the knowledge which I acquired from Mrs. Menuka Arawwawala (Research officer, Herbal Technology section, Industrial Technology Institute). I offer her a very special word of thanks for carefully reading through all my drafts and made a number of useful comments and suggestions. Despite the pressure of work, she made herself available whenever I needed her help and guidance.

Thanks also extended to Dr. C.Wijayasiriwardene (Research officer, Herbal Technology section, Industrial Technology Institute) for his assistance and support for the pharmacognosy part of this study and also to Mrs. V.S. Bandara Mrs. Pushpa Fernando who helped me in numerous ways in providing technical assistance in the laboratory in addition to their other assignments.

I also express my gratitude to all the staff members of Herbal Technology Section at ITI who helped me in numerous ways during the project.

Finally, I wish to express my deepest gratitude to my husband Mr. S.R.R.Silva for his encouragement and moral support during this study. 


\title{
Comparison of Berberine content in Berberis ceylanica vs. market samples of Daruharidra
}

\section{T.K. Nawarathna}

\begin{abstract}
Berberis Linn. (Family: Berberidaceae), a genus of shrubs or small trees, distributed in the temperate and sub tropical parts of Asia, Europe and America. The genus consists of species which are commonly used in many traditional systems of medicines. Berberis aristata DC commonly known as Daruharidra, native to mountainous parts of North India and Nepal. It is an erect glabrous spinescent shrub, 3-6 $\mathrm{m}$ in height with obovate to elliptic, subacute to obtuse, entire or toothed leaves. Flowers in yellow in corymbose racemes, berries oblong-ovoid to ovoid, bright red. Berberis ceylanica Schneider is endemic to Sri Lanka and distributed in mountain forests and forest boarders up to about $2200 \mathrm{~m}$ height. It is a shrub in $3 \mathrm{~m}$ or taller, with ovate, elliptic or obovate, subserrulate or 1-2 spinose leaves. Flowers in yellow in subumbellate racemose, berries ellipsoid to obovoid excluding very short style. Berberine is one of the important alkaloidal active principles of this genus. The present study was carried out to (a) quantify the berberine content and (b) to compare physico-chemical parameters and TLC fingerprints of B. ceylanica and market samples of Daruharidra.
\end{abstract}

Physico-chemical parameters such as moisture content, total ash, acid insoluble ash, water soluble ash, ethanol and water extractable matter were determined for $B$. ceylanica and market samples of Daruharidra. The TLC fingerprints of $B$. ceylanica 
were comparable in terms of $\mathrm{R}_{\mathrm{f}}$ values and color to that of Daruharidra market samples. Hot and cold extraction techniques were used to extract alkaloids from stems of $B$. ceylanica and market samples of Daruharidra. Detection and quantification of berberine were performed by TLC densitometry at the wavelength of $366 \mathrm{~nm}$. The linear regression analysis data for the calibration plot showed a good linear relationship with a correlation coefficient of 0.991 . Berberine content of methanolic extracts of $B$. ceylanica was $1.68 \pm 0.70 \%$. On the other hand there was a wide variation of berberine content in market samples, berberine content of market sample I and market sample II were $1.50 \pm 0.003 \%$ and $2.72 \pm 0.039 \%$ respectively.

In conclusion, this study indicates the similarities in chemical profiles of $B$. ceylanica and market samples of Daruharidra in terms of TLC fingerprints and berberine content and possibility of using B. ceylanica as a substitute of Daruharidra.

Key words: Berberis aristata, Berberis ceylanica, Berberine, Physico-chemical parameters, TLC Densitometry 